\title{
ROLE OF HERBAL MEDICINES IN VITILIGO TREATMENT - CURRENT STATUS AND FUTURE PERSPECTIVES
}

\author{
Radhakrishnan Narayanaswamy ${ }^{1 *}$, Intan Safinar Ismail ${ }^{2}$ \\ ${ }^{1}$ Bio-Incubator and Lab, Vel Tech Technology Incubator, Vel Tech Rangarajan Dr. Sagunthala R \& D Institute of Science and Technology, 400 \\ Feet Outer Ring Road, Avadi, Chennai - 600 062, Tamil Nadu, India. ${ }^{2}$ Laboratory of Natural Products, Institute of Bioscience, Universiti \\ Putra Malaysia, 43400 UPM, Serdang, Selangor, Malaysia. Email: nrkishnan@gmail.com
}

Received: 21 April 2018, Revised and Accepted: 21 May 2018

ABSTRACT

Vitiligo is a depigmentation disorder with complex causes. Nonetheless, recent progress has been made to unravel the pathophysiology of vitiligo. In this review, we provide an overview of the currently known herbal medicine for vitiligo treatment and also highlighted the herbs that have been used in clinical trials. In view of traditional uses, herbs such as Ammi visnaga L., Angelica sinensis, Eclipta alba L, Ginkgo biloba, Picrorhiza kurroa Royle Ex Benth, and Psoralea corylifolia L, have been highlighted. Enormous efforts in vitiligo drug discovery are currently needed. Interleukin-17 inhibition, tumor necrosis factor-alpha inhibition, heat shock protein-70i (HSP70i) inhibition, keratinocyte turnover modulators, and regulatory T cells (Tregs) modulators have been discussed as promising new targets for vitiligo drug development. Thus, we strongly believe that this review may be useful for rationalize new herbal drug for vitiligo treatment.

Keywords: Vitiligo, Melanocyte, Ammi visnaga, Psoralea corylifolia, Regulatory T cells (Tregs) modulators.

(C) 2018 The Authors. Published by Innovare Academic Sciences Pvt Ltd. This is an open access article under the CC BY license (http://creativecommons. org/licenses/by/4. 0/) DOI: http://dx.doi.org/10.22159/ajpcr.2018.v11i9.26830

\section{INTRODUCTION}

Vitiligo is a pigmentation disorder, in which pigmentation cells (melanocytes) of skin are destroyed, which results in smooth, white patches in the midst of normally pigmented skin. People with vitiligo may also associate with eye abnormalities and have a high incidence of diabetes mellitus, pernicious anemia, and thyroid disease [1].

\section{History}

The term vitiligo has been derived from the latin word "vitilus" meaning calf. The term was first coined by Celsus, Roman physician in the $1^{\text {st }}$ Century A.D. [1]. According to him white patches of the disease resembled the white patches of a spotted calf. Vitiligo is an ancient disease mentioned in religious texts such as Holy Quran, Veda, and Bible. The disease is even documented as "Bai Dian Feng" in traditional Chinese medicine, "Shewetakusta" in Indian classic Atharva Veda, "Kilas" in Vinay Pitah (Buddist sacred book) and "Bars," and "Phulbehri" in Arabic and Punjabi language [2].

\section{Prevalence}

It affects approximately 1-2\% of world's population, but the prevalence has been reported as high as $4 \%$ among some South Asian, Mexican, and American populations. In hospital Kuala Lumpur, Malaysia during the period of 2003-2007, approximately $2.2 \%$ new cases have been reported for this disease within the same period [3].

\section{Epidemiology}

It affects individuals of all age, races, ethnicity, and skin types. In Malaysia, vitiligo has been reported among all ethnic races [4]. Dark skin persons (African and Asian) usually face more stigmatization, discrimination and more possibly psychosocial problems [5].

\section{Types of vitiligo}

In general, it is classified according to the distribution, pattern, and extent of depigmentation. According to Nordlund and Lerner [6], it has been classified into three types as i) localized, ii) generalized, and iii) universal vitiligo. Localized vitiligo is again sub-classified as focal and segmental, whereas generalized vitiligo into acrofacial, vulgaris, and mixed subtypes [7].

Pigment biochemistry

Melanin is the major skin pigment, synthesized by specialized cells called melanocytes. Melanin is formed through series of oxidative reactions involving the amino acid tyrosine in the presence of tyrosinase (enzyme). Melanocytes synthesize the melanin within membrane-bound organelles called melanosomes, and later melanosomes are transferred through dendrites to surrounding keratinocytes. Each epidermal melanocyte secretes melanosomes to approximately 40 keratinocytes $(1: 40)$ in the neighborhood, and this entire unit is known as epidermal melanin unit. Thus, the type (eumelanin/pheomelanin) and amount of melanin synthesized by the melanocyte and its distribution in the surrounding keratinocytes determine the actual color of the healthy skin. Four major steps which are involved in melanogenesis process, they are (1) the vdeelopment of melanocyte precursor cells (melanoblasts) and their migration from the neural crest to peripheral sites; (2) differentiation of melanoblasts into melanocytes; (3) survival and proliferation of melanocytes; and (4) formation of melanosomes and production of melanin [8]. All the four steps are important for normal melanin biosynthesis, any disturbance in the melanin pathway results in either hypopigmentation (example albinism and vitiligo) or hyperpigmentation of skin (for example, Addison's disease and melasma).

\section{Etiology of Vitiligo}

Although vitiligo is extensively studied in the past five decades, its etiology is still unclear. 13 prevailing theories of vitiligo (as shown in the Fig. 1) have been reviewed by Speeckaert et al. [9]; however, none of these hypotheses explain the entire spectrum of the vitiligo disease.

\section{Diagnosis of vitiligo}

Wood's light has been used to diagnose the vitiligo in the patients having skin type I and II [10]. 


\section{TREATMENT OF VITILIGO}

Many modalities have been used and continue to be used for the treatment (as shown in Fig. 2).

In spite of different treatment modalities, it is often troublesome and frustrating both for the patients as well as the physician [10]. To date, no Food and Drug Administration approved medical treatments for vitiligo was available [11]. In the present review, we highlight the role of herbal medicine in vitiligo treatment. In the treatment of vitiligo by oral use of Psoralea corylifolia/Ammi majus plant extracts particularly when combined with sun exposure, was known in ancient India, China, Egypt, and Japan [12]. El Mofty [13] was pioneer in Egypt for vitiligo treatment who used the crystallized active components of A. majus mainly 8-methoxypsoralen, both alone and in combination with exposure to sunlight. Later a number of natural psoralens were reported in certain plant families such as Umbelliferae (Parsley, Parsnip, and Celery), Rutaceae (Bergamot fruits, Gas plant, Cloves, and Citrus fruits), and Moraceae (Figs). 13 herbs (as shown in the Table 1) used in the treatment of vitiligo have phototoxic property, which have been used either alone or in combination with sunlight/ultraviolet light (UV).

In addition to these 21 terrestrial plants in Peninsular Malaysia have been reported for phototoxic activity [34]. Another 13 herbs used in the treatment of vitiligo have known to induce melanocyte proliferation, migration and, in turn, stimulant melanogenesis process (as shown in Table 1). In addition to these three herbs have been reported for melanogenic activity [35] two herbs, namely P. corylifolia L and Tribulus terrestris $\mathrm{L}$ reported to have both phototoxic and induce melanocyte proliferation/migration properties. Whereas three herbs such as

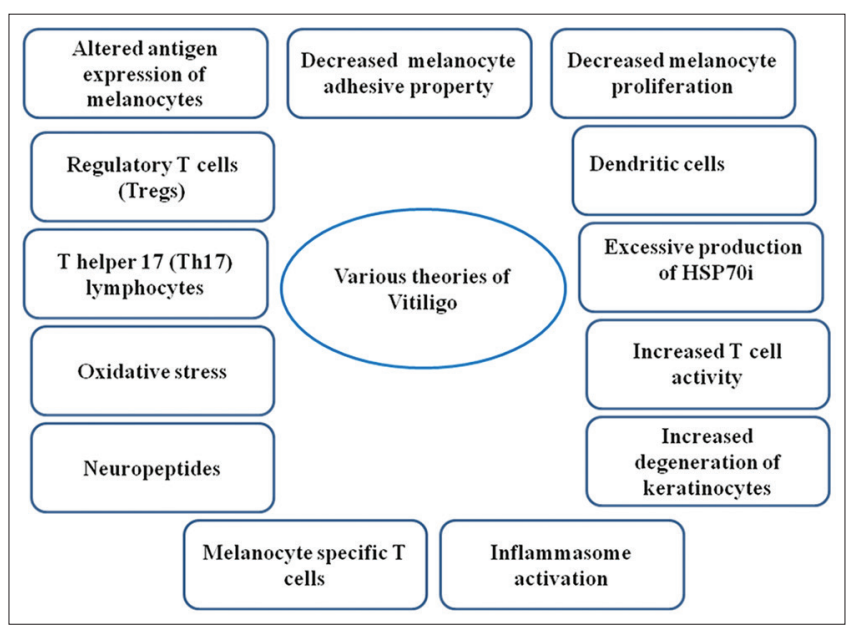

Fig. 1: Represents various theories of Vitiligo

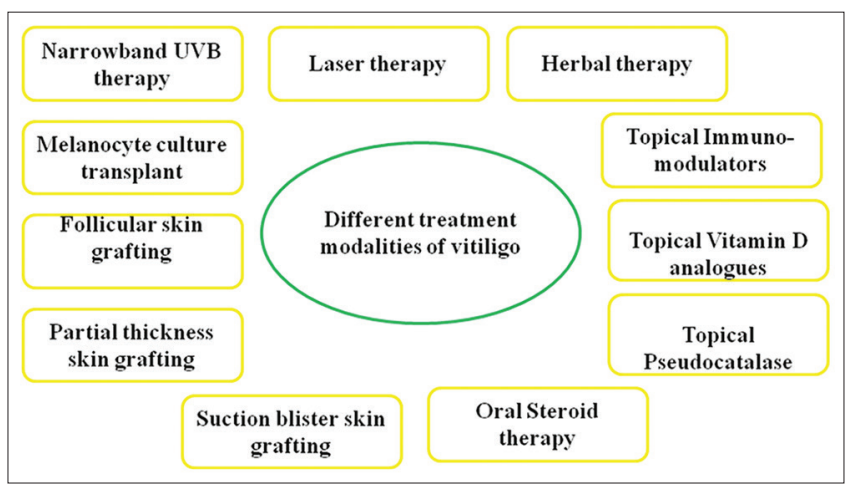

Fig. 2: Represents different treatment modalities of vitiligo
Cnidium officinale, Eclipta alba L, and Eclipta prostrate L reported to have both phototoxic and immunomodulatory properties. Angelica sinensis, only herb reported to have phototoxic, induce melanocyte proliferation/migration, and immunomodulatory properties (as shown in Table 1).

Apart from individual herbs, certain herbal products have been reported for vitiligo treatment includes

1. Anti-vitiligo ${ }^{\mathrm{TM}}$ - An herbal formulation from True Herbals, Lahore, Pakistan and the main herbal ingredients are Berberis vulgaris L., Cocos nucifera L., Nigella sativa L, and P. corylifolia L [1].

2. Callumae - a product, which contains three herbs such as Ammi visnaga L., Ginkgo biloba, and P. kurroa Royle Ex Benth [18].

3. Herbo-mineral capsule (ALG-06), which contains four herbs, namely Azadirachta indica A Juss, P. corylifolia L., Punica granatum L, and Trigonella foenum-graecum L [36].

4. Kakodumbaradi thaila - An herbal formulation which contains four herbs such as Atylosia trinervia (DC.) Gamble, Eclipta prostrata L., Ficus hispida Linn, and Sesamum indicum L [37].

5. Kalawalla ${ }^{\mathrm{R}}$-An herbal formulation from American Lifestyle, New York, USA, and the main herbal ingredients are Polypodium leucotomos, which has been proven to have immune-modulatory activity [1].

6. Tolenorm ${ }^{\mathrm{TM}}$ - a product, which contains five herbs such as Cocos nucifera L., Indigofera tinctoria Linn, Piper longum Linn, P. corylifolia L, and Wrighti tinctoria R.Br [38]

7. Vitilo ${ }^{\mathrm{R}}$ lotion, which contains eight herbs such as Acorus calamus L., A. indica A Juss, Curcuma amada Roxb, Curcuma longa L., Pongamia glabra L., P. corylifolia L., Pterocarpus santalinum L, and Rubia cordifolia L [39].

8. Vitilax - An herbal formulation, which contains 10 herbs, namely $A$. sinensis Oliv, Astragalus membranaceus Fisch, Atractylodes japonica Koidz, Cassia occidentalis L., Cnidium officinale, Curcuma longa L., Cuscuta japonica Choisy, Paeonia lactiflora Pall, Salvia miltiorrhiza, and Tribulus terrestris L [18].

Six trials investigated the use of herbs in the treatment of vitiligo has been discussed by Szczurko and Boon [14]. Four of these clinical trials utilized plants (such as P. kurroa, Ammi visnaga, and two $P$. leucotomos) all were given orally in conjunction with (UVA or UVB) phototherapy; one clinical trial the use of oral Ginkgo biloba (40 mg) alone and another one trial also use the extract of Cucumis melo alone, without any conjunction phototherapy. In a nutshell, no converging results have been drawn for these clinical trials [14]. Apart from these trials, one more pilot trial has been carried using Ginkgo biloba (60 mg) alone [40]. Chakraborthy et al. [41] reported that A. indica A Juss (leaf glycoprotein) inhibits regulatory T cells in cancer, which may also utilize for vitiligo treatment (as this one of an herbal ingredient of Herbo-mineral capsule [ALG-06]). Recently, Zhu et al. [42] reported epigallocatechin-3-gallate (EGCG) from green tea has a new therapeutic agent for vitiligo.

\section{MISCELLANEOUS}

Table 2 provides a comprehensive summary of the patents pertaining to vitiligo treatment using both natural and synthetic products.

Pandey [60] reported a novel ayurvedic formulation (containing of seven herbs such as Aegle marmelos, A. indica, E. alba, Ficus religiosa, Ocimum tenuiflorum, Phylanthus emblica, and P. corylifolia) for the treatment of vitiligo. Recently, Abrus precatorius (seeds), A. majus (seeds), and Pterocarpus marsupium (heartwood) have been used for the treatment of vitiligo [61-63] Mosensons et al. [64] reported that mutant heat shock protein $\left(\mathrm{HSPi}_{\mathrm{Q} 435 \mathrm{~A}}\right)$ as a potent agent for treating vitiligo.

\section{FUTURE PERSPECTIVES}

In recent years efforts to discover and develop new vitiligo drugs have gained much attention among the researchers, as result of 
Table 1: Herbs used for Vitiligo treatment

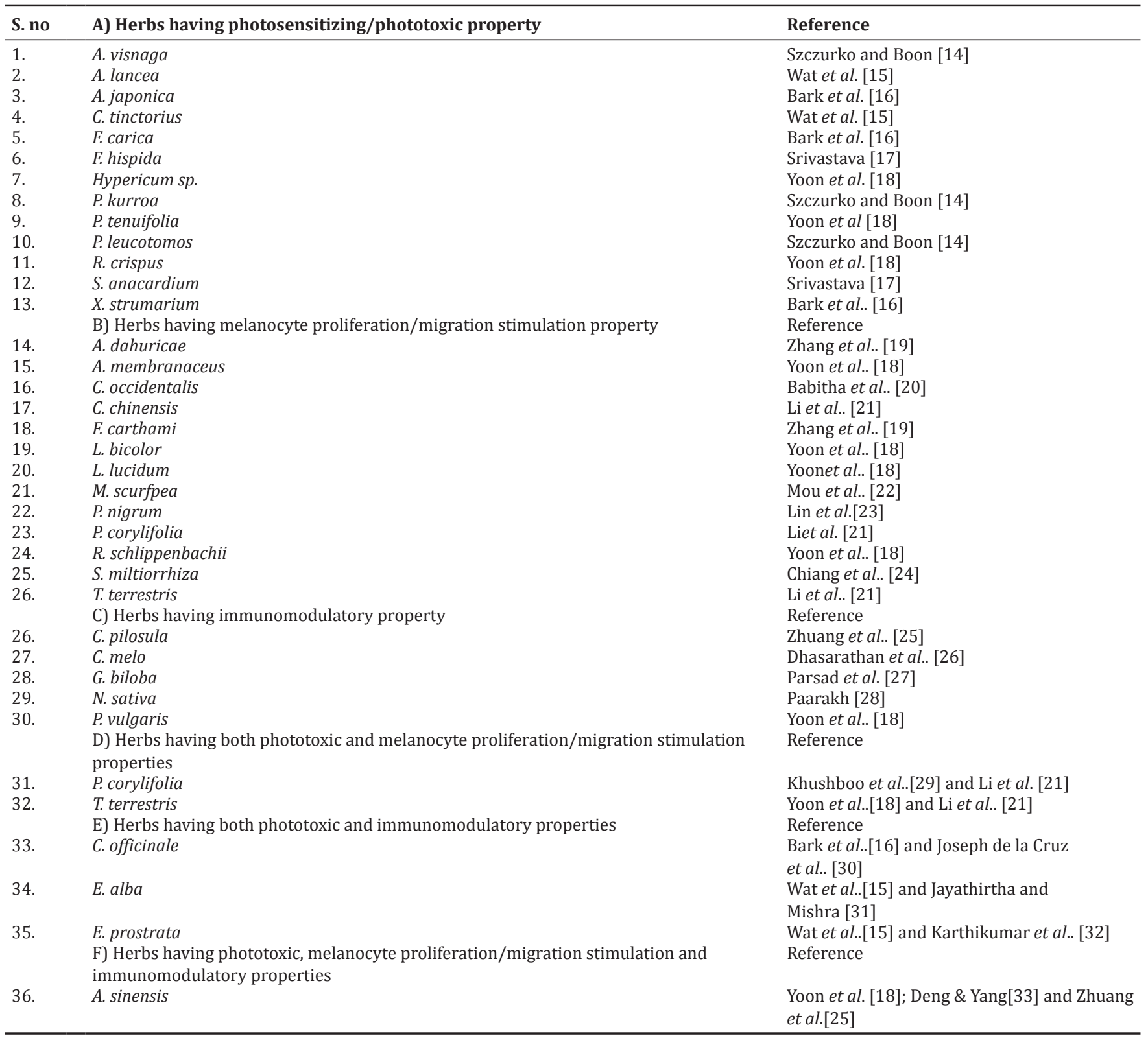

A visnaga: Ammi visnaga, A. lancea: Atractylodes lancea, A. japonica: Atractylodes japonica, C. tinctorius: Carthamus tinctorius, F. carica: Ficus carica, F. hispida: Ficus hispida, P. kurroa: Picrorhiza kurroa, P. tenuifolia: Polygala tenuifolia, P. leucotomos: Polypodium leucotomos, R. crispus: Rumex crispus, S. anacardium: Semecarpus anacardium, X. strumarium: Xanthium strumarium, A. dahuricae: Angelicae dahuricae, A. membranaceus: Astragalus membranaceus, C. occidentalis: Cassia occidentalis, C. chinensis: Cuscuta chinensis, F. carthami: Flos carthami, L. bicolor: Lespedeza bicolor, L. lucidum: Ligustrum lucidum, M. scurfpea: Malytea scurfpea, P. nigrum: Piper nigrum, P. corylifolia: Psoralea corylifolia, R. schlippenbachii: Rhododendron schlippenbachii, S. miltiorrhiza: Salvia miltiorrhiza, T. terrestris: Tribulus terrestris, C. pilosula: Codonopsis pilosula, C. melo: Cucumis melo, G. biloba: Ginkgo biloba, N. sativa: Nigella sativa, P. vulgaris: Prunella vulgaris, P. corylifolia: Psoralea corylifolia, T. terrestris: Tribulus terrestris, C. officinale: Cnidium officinale, E. alba: Eclipta alba, E. prostrate: Eclipta prostrate, A. sinensis: Angelica sinensis

the recognition of the worldwide importance of fighting vitiligo disease. Moreover, world vitiligo day has been observed on June 25 every year as a way to create global awareness. There is a high need to have public-private collaboration and long-term action plan to discover, develop, and deliver new drugs for vitiligo treatment. Recent understanding the multifactorial, multistep etiology of vitiligo, has identified many potential targets for new drugs. New promising targets may include Interleukin-17 (IL-17) inhibition, tumor necrosis factor-alpha inhibition, heat shock protein-70i (HSP70i) inhibition, keratinocyte turnover modulators, and regulatory T cells (Tregs) modulators. Time is our tough judge, and really no one wants to loss the golden opportunity to develop new, safe, affordable, and effective vitiligo drugs from a natural source.

\section{AUTHOR'S CONTRIBUTIONS}

RN (first author), who wrote the manuscript and submitted the same as part of PDF programme. Intan (research supervisor), who had added value to it. All authors read and approved the final manuscript.

\section{CONFLICTS OF INTEREST}

The authors have declared no conflicts of interest. 
Table 2: Patents pertaining to Vitiligo treatment

\begin{tabular}{|c|c|c|c|c|}
\hline S.no & Patent (Country) & Year & Important claim & Reference \\
\hline 1. & $\begin{array}{l}\text { United States (US) } \\
\text { patent }\end{array}$ & 2014 & $\begin{array}{l}\text { Preventing or treating vitiligo using Pueraria genus plant extract or puerarin as an } \\
\text { active agent. }\end{array}$ & Kim et al. [43] \\
\hline 2. & $\begin{array}{l}\text { United States (US) } \\
\text { patent }\end{array}$ & 2013 & $\begin{array}{l}\text { Treating vitiligo using Stachytarpheta species plant extract or its active } \\
\text { constituent/s or its derivatives. }\end{array}$ & Ferreira [44] \\
\hline 3. & $\begin{array}{l}\text { European } \\
\text { patent }(\mathrm{EP})\end{array}$ & 2007 & $\begin{array}{l}\text { Treating vitiligo using Pimienta racemosa extract along with Cucumis melo, Citrus } \\
\text { aurantifolia, coenzyme Q10, and pyridoxine chlorhydrate }\end{array}$ & $\begin{array}{l}\text { Paleo and } \\
\text { Rojas [45] }\end{array}$ \\
\hline 4. & $\begin{array}{l}\text { European } \\
\text { patent (EP) }\end{array}$ & 2014 & Treating vitiligo using Vigna unguiculata seed extract. & $\begin{array}{l}\text { Msika } \\
\text { et al }[46]\end{array}$ \\
\hline 5. & $\begin{array}{l}\text { European } \\
\text { patent (EP) }\end{array}$ & 2010 & Treating vitiligo using Lycium barbarum (wolfberry) extract & $\begin{array}{l}\text { Vidal } \\
\text { et al. }[47]\end{array}$ \\
\hline 6. & $\begin{array}{l}\text { United States (US) } \\
\text { patent }\end{array}$ & 2014 & $\begin{array}{l}\text { Treating vitiligo using nerve growth factor (NGF) of human/murine/recombinant } \\
\text { origin along with other ingredients. }\end{array}$ & Liotta $[48]$ \\
\hline 7. & $\begin{array}{l}\text { United States (US) } \\
\text { patent }\end{array}$ & 2015 & Treating vitiligo using fluoxetine & $\begin{array}{l}\text { Shang } \\
\text { et al. }[49]\end{array}$ \\
\hline 8. & $\begin{array}{l}\text { United States (US) } \\
\text { patent }\end{array}$ & 2015 & Treating vitiligo using rapamycin along with other ingredients. & Bacus [50] \\
\hline 9. & $\begin{array}{l}\text { United States (US) } \\
\text { patent }\end{array}$ & 2015 & Treating vitiligo using pentapeptides (example: YSSWY/YRSRK). & $\begin{array}{l}\text { Hantash and } \\
\text { Ubeid [51] }\end{array}$ \\
\hline 10. & $\begin{array}{l}\text { United States (US) } \\
\text { patent }\end{array}$ & 2015 & $\begin{array}{l}\text { Treating vitiligo using rapamycin along with other ingredients, especially } \\
\text { forskolin/colforsin (cAMP activator agent). }\end{array}$ & $\begin{array}{l}\text { Bacus and } \\
\text { Moran [52] }\end{array}$ \\
\hline 11. & $\begin{array}{l}\text { United States (US) } \\
\text { patent }\end{array}$ & 2015 & $\begin{array}{l}\text { Treating vitiligo using compounds } \\
\text { I \{N2-3-aminosulfonyl-4-methylphenyl-5-fluoro-N4-[4-(prop-2ynyloxy) } \\
\text { phenyl]-2,4-pyrimidinediamine }\} \text { and } \\
\text { II \{5-fluoro-N2-(4-methyl-3-propionylaminosulfonylphenyl)-N4-[prop-2-ynyloxy) } \\
\text { phenyl]-2,4-pyrimidinediamine }\}\end{array}$ & Magilavy [53] \\
\hline 12. & $\begin{array}{l}\text { Worldwide (WO) } \\
\text { patent }\end{array}$ & 2015 & $\begin{array}{l}\text { Treating vitiligo using aromatic-cationic peptides, especially D-Arg-2', } \\
\text { 6'-Dmt-Lys-Phe-NH2. }\end{array}$ & Wilson [54] \\
\hline 13. & $\begin{array}{l}\text { Korean } \\
\text { patent }(\mathrm{KR})\end{array}$ & 2011 & Treating vitiligo using Cassia occidentalis extract. & Kim et al. [55] \\
\hline 14. & $\begin{array}{l}\text { Korean } \\
\text { patent }(\mathrm{KR})\end{array}$ & 2011 & Treating vitiligo using Cassia alata extract. & Kim et al [56] \\
\hline 15. & $\begin{array}{l}\text { Korean } \\
\text { patent }(\mathrm{KR})\end{array}$ & 2015 & $\begin{array}{l}\text { Treating vitiligo using liquiritigenin (active compound isolated from Glycyrrhizae } \\
\text { radix extract). }\end{array}$ & Ku et al. [57] \\
\hline 16. & $\begin{array}{l}\text { United States (US) } \\
\text { patent }\end{array}$ & 1997 & $\begin{array}{l}\text { Treating vitiligo using glycosphingolipids and endothelin-like peptide } \\
\text { (human placenta extract). }\end{array}$ & $\begin{array}{l}\text { Bhadra } \\
\text { et al }[58]\end{array}$ \\
\hline 17. & $\begin{array}{l}\text { Chinese } \\
\text { patent }(\mathrm{CN})\end{array}$ & 2016 & $\begin{array}{l}\text { Treating vitiligo using herbal composition comprises of Syzygium cumini, } \\
\text { Thermopsis barbata, Ajuga lupulina, Primula sikkimensis, and Corydalis hendersonii } \\
\text { extract }\end{array}$ & $\begin{array}{l}\text { Shao } \\
\text { Peicai [59] }\end{array}$ \\
\hline
\end{tabular}

\section{REFERENCES}

1. Abu Tahir M, Pramod K, Ansari SH, Ali J. Current remedies for vitiligo. Autoimmun Rev 2010;9:516-20.

2. Ansari FZ, Alam S, Jain P, Akhter S, Ansari MZ. Vitiligo and its herbal treatment. Pharm Rev 2008;12:137-9.

3. Adauwiyah J, Suraiya HH. A retrospective study of narrowband-UVB phototherapy for treatment of vitiligo in Malaysian patients. Med J Malaysia 2010;65:299-1.

4. Wong SM, Baba R. Quality of life among Malaysian patients with vitiligo. Int J Dermatol 2012;51:158-61.

5. Mattoo SK, Handa S, Kaur I, Gupta N, Malhotra R. Psychiatric morbidity in vitiligo: Prevalence and correlates in India. J Eur Acad Dermatol Venereol 2002;16:573-8.

6. Nordlund JJ, Lerner AB. Vitiligo: It is important. Arch Dermatol 1982;118:5-8.

7. Shajil EM, Chatterjee S, Agrawal D, Bagchi T, Begum R. Vitiligo: Pathomechanisms and genetic polymorphism of susceptible genes. Indian J Exp Biol 2006;44:526-39.

8. Costin GE, Hearing VJ. Human skin pigmentation: melanocytes modulate skin color in response to stress. FASEB J 2007;21:976-94

9. Speeckaert R, Speeckaert MM, van Geel N. Why treatments do (n't) work in vitiligo: An autoinflammatory perspective. Autoimmun Rev 2014; 14:332-40.

10. Soni P, Patidar R, Soni V, Soni S. A Review on traditional and alteranative treatment for skin disease "vitiligo". Int J Pharm Biol Arch 2010;1:220-7.

11. Rashighi M, Agarwal P, Richmond JM, Harris TH, Dresser K, Su MW, et al. CXCL10 is critical for the progression and maintenance of depigmentation in a mouse model of vitiligo. Sci Transl Med 2014;6:223ra23.

12. Lindsay HC. Leukoderma - its treatment. Cal West Med 1932;37:36-41.

13. El Mofty AM. A preliminary clinical report on the treatment of leucoderma with Ammi majus Linn. J Egypt Medl Assoc 1948;31:651-65.

14. Szczurko O, Boon HS. A systematic review of natural health product treatment for vitiligo. BMC Dermatol 2008;8:2.

15. Wat CK, Johns T, Towers GN. Phototoxic and antibiotic activities of plants of the Asteraceae used in folk medicine. J Ethnopharmacol 1980;2:279-90.

16. Bark KM, Heo EP, Han KD, Kim MB, Lee ST, Gil EM, et al. Evaluation of the phototoxic potential of plants used in oriental medicine. J Ethnopharmacol 2010;127:11-8.

17. Srivastava RK. Vitiligo (leukoderma) Ayurvedic Treatment-2011. Available from: http://www.ayurveda-foryou.com/treat/leucoderma. html.

18. Yoon J, Kim TH, Sun YW. Complementary and Alternative Medicine for Vitiligo: Vitiligo-Management and Therapy. In: Park KK, Murase JE, editors. Croatia, Europe: InTech Publisher; 2011.

19. Zhang X, Feng J, Mu K, Ma H, Niu X, Liu C, et al. Effects of single herbal drugs on adhesion and migration of melanocytes. J Tradit Chin Med 2005;25:219-21.

20. Babitha S, Shin JH, Nguyen DH, Park SJ, Reyes GA, Caburian A, et al. A stimulatory effect of Cassia occidentalis on melanoblast differentiation and migration. Arch Dermatol Res 2011;303:211-6.

21. Li HW, Zhu WY, Xia MY. Melanogenic effects of ethanol extracts obtained from 5 traditional Chinese medicines on shape and properties of melanocytes from skin of brownish guinea pigs. J Clin Dermatol 2001;30:69-71.

22. Mou KH, Zhang XQ, Yu B, Zhang ZL, Feng J. Promoting of melanocyte adhesion and migration by Malytea Scurfpea fruit in vitro. Methods 
Find Exp Clin Pharmacol 2004;26:167-70.

23. Lin Z, Hoult JR, Bennett DC, Raman A. Stimulation of mouse melanocyte proliferation by Piper nigrum fruit extract and its main alkaloid, piperine. Planta Med 1999;65:600-3.

24. Chiang SH, Chen YS, Hung MS, Lee SM, Lin CC. The enhancement effect of Salvia miltiorrhiza on melanin production of $\mathrm{B} 16 \mathrm{~F} 10$ melanoma cells. J Med Plant Res 2012;6:4338-42.

25. Zhuang SR, Chiu HF, Chen SL, Tsai JH, Lee MY, Lee HS, et al. Effects of a Chinese medical herbs complex on cellular immunity and toxicityrelated conditions of breast cancer patients. Br J Nutr 2012;107:712-8.

26. Dhasarathan P, Gomathi R, Theriappan P, Paulsi S. Immunomodulatory activity of alcoholic extract of different fruits in mice. J Appl Sci Res 2010;6:1056-9.

27. Parsad D, Pandhi R, Juneja A. Effectiveness of oral Ginkgo biloba in treating limited, slowly spreading vitiligo. Clin Exp Dermatol 2003;28:285-7.

28. Paarakh PM. Nigella sativa Linn.-a comprehensive review. Indian J Nat Prod Resour 2010;1:409-29

29. Khushboo PS, Jadhav VM, Kadam VJ, Sathe NS. Psoralea corylifolia Linn.-_Kushtanashini”. Pharmacogn Rev 2010;4:69-76.

30. de la Cruz J, Lee WS, Hwang SG. Immunomodulatory effect of Cnidium officinale Makino extract in murine peritoneal macrophages and splenocytes. World J Pharm Pharm Sci 2013;2:867-77.

31. Jayathirtha MG, Mishra SH. Preliminary immunomodulatory activities of methanol extracts of Eclipta alba and Centella asiatica. Phytomedicine 2004;11:361-5.

32. Karthikumar S, Jegatheesan K, Thangaraja A, Banupriya K, Dhivya T, Malarvizhi JM. Immunomodulatory activity of Eclipta prostrata in SRBC immunized mice. J Pharmacog Phytother 2011;3:52-5.

33. Deng Y, Yang L. Effect of Angelica sinensis (Oliv.) on melanocytic proliferation, melanin synthesis and tyrosinase activity in vitro. Di Yi Jun Yi Da Xue Xue Bao 2003;23:239-41.

34. Ong CY, Ling SK, Ali RM, Chee CF, Samah ZA, Ho AS, et al. Systematic analysis of in vitro photo-cytotoxic activity in extracts from terrestrial plants in Peninsula Malaysia for photodynamic therapy. J Photochem Photobiol B Biol 2009;96:216-22.

35. Radhakrishnan N, Intan SI. Cosmetic potential of Southeast Asian herbs: An overview. Phytochemy Rev 2015;14:419-28.

36. Huma A, Rizwani GH, Usman M, Ishaque S, Ansari SA, Anwer S. Drug development of herbomineral capsule (ALG-06) used for hypopigmentation specially in vitiligo. Pak J Pharm Sci 2014;27:1451-7.

37. Ediriweera ER, Kalawana OT, Karunarathna N, Nanayakkara NG. Clinical study on efficacy of the traditional Sri Lankan oil' the Kakodumbaradi Taila' with selected ayurvedic preparations on shvitra (vitiligo). AYU 2009;30:225-31.

38. Available from: http://www.jrksiddha.com/products/tolenorm_oil.htm.

39. Madan R, Asrani F. In: Norman RA, Sheneflt PD, Rupani RN, editors. Integrative Management of Vitiligo: Integrative Dermatology. UK: Oxford University Press, Weil Integrative Medicine Library Series; 2014.

40. Szczurko O, Shear N, Taddio A, Boon H. Ginkgo biloba for the treatment of vitilgo vulgaris: An open label pilot clinical trial. BMC Complementary Altern Med 2011;11:21.

41. Chakraborty T, Bose A, Barik S, Goswami KK, Banerjee S, Goswami S, et al. Neem leaf glycoprotein inhibits CD4+ CD25+ Foxp3+ Tregs to restrict murine tumor growth. Immunotherapy 2011;3:949-69.

42. Zhu Y, Wang S, Lin F, Li Q, Xu A. The therapeutic effects of EGCG on vitiligo. Fitoterapia 2014;99:243-51.

43. Kim HJ, Park WS, Koh HJ, Min DJ, Park NH, Park PJ, et al. Composition for Preventing or Treating Poliosis or Vitiligo Comprising a Pueraria Genus plant Extract or Puerarin. US Patent No. 2014:8901088.

44. Ferreira EQ. Pharmaceutical Composition on the Basis of Stachytarpheta sp., a Process for Obtaining the same and its use for Treating Vitiligo. US Patent No. 2013:20130287868.

45. Paleo RA, Rojas UJ. Natural Product in Cream with Anti-vitiligo Therapeutic Properties. EP No. 2007:1747786.

46. Msika P, Saunois A, Leclere-Bienfait S, Baudoin C. Vigna unguiculata Seed Extract and Compositions Containing Same. EP No. 2014:2506724.

47. Vidal K, Blum-Sperisen S, Philippe D, Ballevre O, Bucheli P, Wang J. Wolfberries and Skin Inflammation. EP No. 2010:2200624.

48. Liotta S. Topical Preparation Containing ngf for Inducing Skin Pigmentation and for the Treatment of Cutaneous Dyschromias and Vitiligo. US Patent No. 2014:0242007.

49. Shang J, Liao S, Jin Y, Tian X, Zhao G, Zhou J, et al. Application of Fluoxetine to Treatment of Depigmentation Diseases. US Patent No. 2015:0065580

50. Bacus S. Compositions and Methods for Treatment of Vitiligo. US Patent No. 2015:8946256.

51. Hantash BM, Ubeid AA. Peptide Tyrosinase Activators. US Patent No. 2015:0152139.

52. Bacus S, Moran D. Compositions and Methods for Treatment of vitiligo. US Patent No. 2015:0202187.

53. Magilavy D. Treatment for Vitiligo. US Patent No. 2015:9034881.

54. Wilson DT. Compositions and Methods for Treating Vitiligo. WO No. 2015:084875.

55. Kim EK, Shin JH, Babitha S, Reyes G, Adeltrudes C. A Pharmaceutical Composition Comprising Extract of Cassia occidentalis as an Active Ingredient for Treatment of Vitiligo. KR No. 2011:0008609.

56. Kim EK, Shin JH, Babitha S, Reyes G, Adeltrudes C. A Pharmaceutical Composition Comprising Extract of Cassia occidentalis as an Active Ingredient for Treatment of Vitiligo. KR No. 2011:0008609.

57. Ku CS, Kim MJ, Jang DI. Composition Comprising the Liquiritigenin for Prevention and Treatment of Vitiligo. KR No. 2015:0118670.

58. Bhadra R, Pal P, Roy R, Dutta AK. Process for the preparation of an extract from human placenta containing glycosphingolipids and endothelin-like constituent peptides useful for the treatment of vitiligo. US Patent No. 1997:5690966.

59. Peicai S. Medicinal Composition for Treating Childhood Vitiligo. CN No. 2016:105343195.

60. Pandey RS. Discovery of novel ayurvedic formulation for the treatment of vitiligo. Asian J Med Sci 2015;6:132-3.

61. Jain A, Sinha P, Jain A, Vavilala S. Estimation of flavonoid content, polyphenolic content and antioxidant potential of different parts of Abrus precatorius (L). Int J Pharm Pharm Sci 2015;7:157-63.

62. Adham AN. Simultaneous estimation of caffeic and chlorogenic acid content in Ammi majus seed by TLC and HPLC. Int J Pharm Pharm Sci 2015;7:263-7

63. Katiyar D, Singh V, Ali M. Isolation, characterization and prediction of biological activity of two new fatty esters and a phenol from the heartwood of Pterocarpus marsupium Roxb. Int J Pharm Pharm Sci 2017;9:117-22.

64. Mosenson JA, Zloza A, Nieland JD, Garrett-Mayer E, Eby JM, Huelsmann EJ, et al. Mutant HSP70 reverses autoimmune depigmentation in vitiligo. Sci Transl Med 2013;5:174ra28. 